\title{
SYNCHRONOUS DEVELOPMENT OF SCHWANNOMA AND PRIMARY ADENOCARCINOMA IN THE STOMACH: A CASE REPORT
}

\author{
Algirdas Šlepavičius ${ }^{1}$, Valdas Gasilionis ${ }^{2}$, Alvydas Česas $^{3}$ \\ ${ }^{1}$ Klaipeda University Hospital, Department of Abdominal and Endocrine Surgery, Lithuania, \\ ${ }^{2}$ Klaipeda University Hospital, Department of Pathology, Lithuania, \\ ${ }^{3}$ Klaipeda University Hospital, Department of Oncology, Lithuania
}

Key words: gastric schwannoma, adenocarcinoma.

\begin{abstract}
Summary
Schwannomas are generally benign, slow growing tumors, which can originate from any nerve that has a Schwann cells health. Stomach schwannomas are very rare gastrointestinal mesenchymal tumor which represents only $0,2 \%$ of all gastric tumors. The simultaneous occurrence of adenocarcinoma and schwannoma is extremely rare in the stomach. Only two such cases has been previously reported. We present the case of 52-years-old female with asymptomatic schwannoma and simultaneous carcinoma of the stomach.
\end{abstract}

\section{Introduction}

Schwannomas, also known as neurillemmomas are benign neurogenic tumors, originating from Schwann cells, which normally wrap around the axons of the peripheral nerves. These tumors are usually benign, slow-growing and asymptomatic [1]. Gastric schwannomas occur more frequently in the fifth to sixth decade of life and are more common in female patients [10]. Theoretically, schwannomas can develop anywhere along the peripheral course of a nerve. However, they most commonly occur in the head and neck, but rarely in the gastrointestinal tract [12]. Schwannomas represent $6.3 \%$ of gastric mesenchymal tumours and only $0.2 \%$ of all gastric tumors. They are usually located in the middle third of the stomach along the lesser curvature $[1,12]$.

Objective: to present unusual and rare clinical case of synchronous development of schwannoma and primary adenocarcinoma in the stomach.

\section{Case report}

A 52-year-old female with a history of hypertension and tension headaches was diagnosed with a renal clear cell car- cinoma two years ago and had a radical nephrectomy.

Surveillance abdominal contrast enhanced computed tomography scan showed a well-defined, homogenous, round mass in the fundus of the stomach, enlargement of lymph nodes: para-aortic and located along the gastric lesser curvature - the largest one being $1,5 \mathrm{~cm}$ in size (Fig.1).

Endoscopy demonstrated a $0,8 \mathrm{~cm}$ ulcer in the gastric antrum. The endoscopic biopsy specimen taken from the gastric ulcerating lesion was diagnosed to be adenocarcinoma. But no submucosal mass and no ulcerated mucosa was found in the fundus.

After presenting the case at our multidisciplinary meeting, a consensus was reached to proceed with diagnostic laparoscopy and lymph node biopsy. Having dissemination of adenocarcinoma to the lymph nodes detected, further preoperative neoadjuvant chemotherapy would have been opted, whereas non-metastatic disease would have been treated by gastrectomy. Intraoperatively, three centimeter exophytic mass was identified along the greater curvature in the gastric fundus (Fig.2). Enlarged lymph nodes were excised along the common hepatic artery laparoscopically. Intraoperative pathologic examination of lymph nodes revealed no evidence of metastatic disease. Operation was converted to a laparotomy: subtotal gastrectomy with Billroth II anastomosis, D2 lymphadenectomy with total omentectomy and resection of the mass in the fundus of the stomach were performed. Intraoperative pathologic examination of the fundic mass showed a benign formation representing a mesenchymal tumour. Final histopathology confirmed the presence of moderately differentiated (G2) adenocarcinoma of the gastric antrum (pT1B pN0) intestinal type by Lauren classification (Fig.3). The resected neoplastic mass in the fundus was polypoid, partially encapsulated and measured $2,5 \times 2,3 \mathrm{~cm}$. It was composed of spindle cells with compact Antoni A areas. No mitotic figures or significant cellular atypia was present. The tumour cells were diffusely and strongly immunoreactive for 
S-100 protein and weakly positive for alpha smooth muscle actin. Focal CD34 staining was seen. Neoplastic cells lacked immunoreactivity for CD117, desmin, calretinin and epithelial membrane antigen (EMA). Proliferation index Ki-67 was low (5\%). The histologic features were consistent with schwannoma (Fig.4). Three years after the surgery patient feels good and is free of disease.

\section{Discussion}

Gastric adenocarcinomas account for approximately $95 \%$ of all malignant gastric tumors. It is the most common form of stomach cancer. Most synchronous tumours are combination of either adenocarcinoma and low grade B-cell lymphoma or adenocarcinoma and carcinoid [7]. Synchronous occurrence of gastric adenocarcinoma and gastric mesenchymal tumour is very rare: only 14 cases of synchronous gastric adenocarcinoma and GIST have been reported [5,8,9].

The synchronous occurrence of an adenocarcinoma and

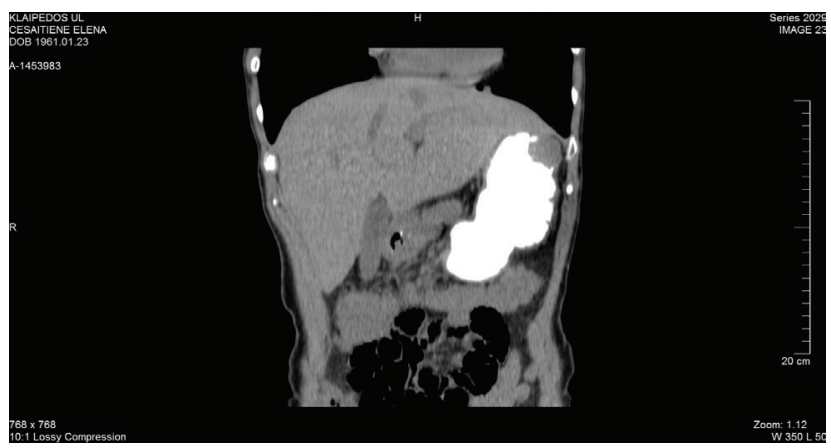

Figure 1. Computerized tomography scanning of the upper abdomen demonstrating a mass lesion in the fundus of the stomach.

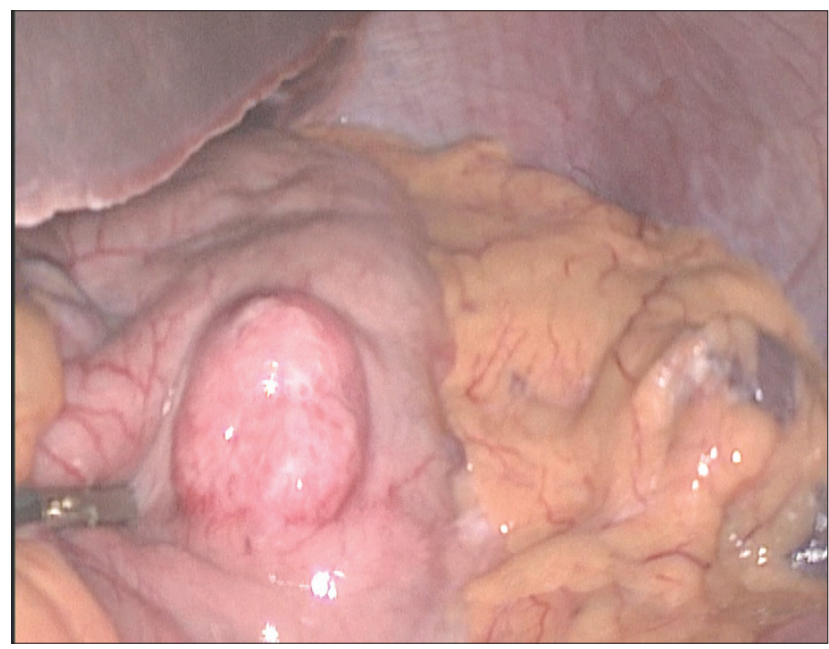

Figure 2. Intraoperative view of exophytic mass along the greater curvature of anterior wall of gastric fundus. schwannoma in the stomach is extremely rare with only two cases have been reported previously. The first publication reported a case of schwannoma and adenocarcinoma presenting as two separate masses [5], while the second one presented collision of these tumors [6].

Schwannomas, also known as neurillemmomas are benign neurogenic tumors, originating from Schwann cells, which normally wrap around the axons of the peripheral nerves. These tumors are usually benign, slow-growing and asymptomatic [1]. Gastric schwannomas occur more frequently in the fifth to sixth decade of life and are more common in female patients [10]. Theoretically, schwannomas can

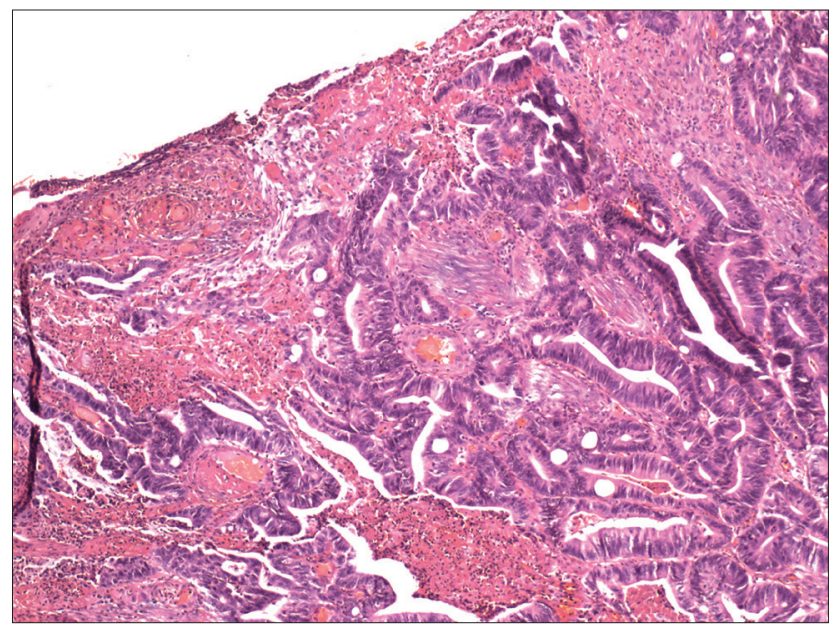

Figure 3. H@E section for the gastric ulcerated tumor, showing irregular cribriform structures, lined by tall, columnar atypical epithelium with numerous mitotic figures.

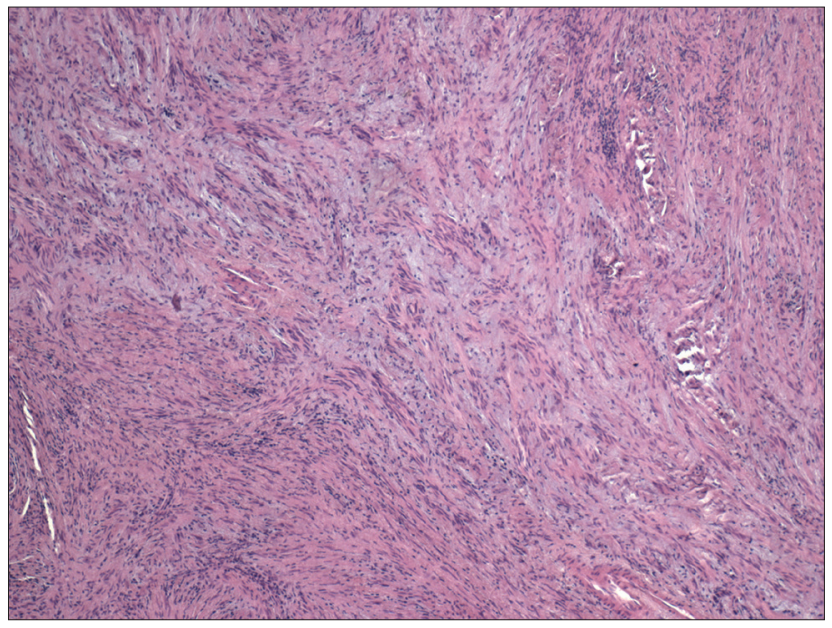

Figure 4.H@E section of the polypoid gastric mass, showing monomorphic population of spindle cells in collagenous matrix. No significant nuclear atypia or mitoses were present. 
develop anywhere along the peripheral course of a nerve. However, they most commonly occur in the head and neck, but rarely in the gastrointestinal tract [12]. Schwannomas represent $6.3 \%$ of gastric mesenchymal tumours and only $0.2 \%$ of all gastric tumors. They are usually located in the middle third of the stomach along the lesser curvature $[1,12]$.

Schwannomas generally present asymptomatically, however, in some cases they can cause abdominal discomfort, pain or digestive symptoms. A palpable mass may also be present if the tumour is large and exophytic. In cases with deep ulceration, bleeding may also be present [10].

Diagnosis is often delayed because symptoms may not occur in the early stages of the disease. The differential diagnosis of a submucosal gastric mass is broad and includes GIST, leiomyoma, leiomyosarcoma, and schwannoma, among others [12].

Endoscopic examination can offer a good visualization to the lesion for the diagnosis and surgery. The typical endoscopic appearance of gastric schwannoma is a round protruding mass with an overlying ulcerated mucosa. False negative results of the endoscopic biopsy could be encountered due to normal mucosa overlying the submucosal lesion [17]. Endoscopic ultrasound guided fine -needle aspiration biopsy is currently considered the standard method for samples of submucosal tumors of stomach[19 ]. Imaging modalities such as computed tomography (CT), ultrasound, and magnetic resonance imaging (MRI) can provide limited but useful information. Schwannomas often appear uniform on CT, feature, that can help distinguish them from leiomyomas and leiomyosarcomas; ultrasound with a sufficient resolution can determine the tumors' layers of origin, and MRI can map the precise location of the tumor and displacement of surrounding organs $[11,13,14,15]$. In the largest published study of 14 consecutive cases of gastric schwannomas a preoperative diagnosis of schwannoma was not obtained in the majority of cases $(13 / 14,93 \%)$ [20].

Microscopically schwannomas consist of spindle cells. Two main patterns of cellular organization are seen: compact areas, where cells are arranged in streams and areas of palisading (Antoni A) and loosely arranged cells, often with areas of vacuolation and occasionally lipidisation (Antoni B). Verrocay bodies are seen in a proportion of tumours in Antoni A regions. Secondary and degenerative changes are common in schwannomas [1].

The immunohistochemical features of schwannomas are very important for the differential diagnosis between the various types of submucosal tumors, such as GISTs, leiomyomas and others. Immunohistochemistry shows no epithelial antigens expressed by tumor cells, which have the phenotype of Schwann cells [17]. Digestive tract schwanno- mas are $\mathrm{S} 100$ protein and vimentin positive, never express the CD 117 antigen and are usually negative for CD 34, in contrast to GISTs [16]. Schwannomas are also negative for smooth muscle actin (SMA), in contrast to leiomyomas [17]. GANTs on the other hand, are usually negative for S-100 protein and glial fibrillary acidic protein (GFAP) and most are positive for CD 117 and CD 34[16]. Schwannomas of the gastrointestinal tract are GFAP positive in contrast to peripheral schwannomas [1].

Due to the difficulty of establishing a definite preoperative diagnosis, but also in order to prevent possible complications such as bleeding or pyloric stenosis, surgical resection should be considered the treatment of choice in patients with gastric schwannoma. The size and location of the tumor, as well as its relation to the surrounding organs are important factors in determining the type of operation. Local endoscopic extirpations, wedge resection, partial, subtotal or even total gastrectomy, are all acceptable operations [17]. Laparoscopic techniques can also be applied [18]. Schwannomas do not recur when completely excised [17].

The simultaneous finding of epithelial and stromal gastric tumors raises the question of whether or not such an occurrence is a simple incidental association or the two lesions are connected by a causal relationship. The formation of two histologically different tumors could easily be coincidental; nevertheless there are hypotheses that a single carcinogenic agent under certain circumstances could be responsible for such dichotomous neoplastic formations in the neighboring tissues [8]. In addition, genetic predisposition underlining these tumors should not be discharged as a cause in those cases where familial disease is present. However, recent study of gastric adenocarcinoma patients who had simultaneous GIST, showed no obvious genetic relationship between gastric cancer and GIST tumorigenesis [2].

\section{Conclusions}

More work is required to clarify the mechanisms, underlying the pathogenesis of synchronous gastric epithelial and mesenchymal tumours. We presented an example of two independent gastric tumours in a unique combination, namely, synchronous gastric adenocarcinoma and schwannoma.

Consent

Written informed consent was obtained from the patient for publication of this case report and accompanying images.

Conflict of interest

The authors declare that there is no conflict of interests regarding the publication of this article. 


\section{References}

1. Hou YY TYS, Xu JF, Wang XN, Lu SH, Ji Y. et al. Schwannoma of the gastrointestinal tract: a clinicopathological, immunohistochemical and ultrastructural study of 33 cases. Histopathology 2006;48:605-613. https://doi.org/10.1111/j.1365-2559.2006.02370.x

2.Miettinen M LJ. Gastrointestinal stromal tumors-definition, clinical, histological, immunohistochemical, and molecular genetic features and differential diagnosis. Virchows Arch 2001;438:1-12.

https://doi.org/10.1007/s004280000338

3. Miettinen M MM, Lasota J. Pathology and diagnostic criteria of gastrointestinal tumors (GISTs): a review. Eur J Cancer 2002;38:39-51.

https://doi.org/10.1016/S0959-8049(02)80602-5

4. Yan Y LZ, Liu Y, Zhang L, Li J, Ji J. Coexistence of gastrointestinal stromal tumors and gastric adenocarcinomas. Tumor Biol 2013;34:919-927.

https://doi.org/10.1007/s13277-012-0627-5

5. Yang KY, Park HS, Chung MJ. Synchonous occurrence of primary adenocarcinoma and schwannoma in the stomach: a case report. Pathology 2009;41:286-289.

https://doi.org/10.1080/00313020902756386

6. Jai Hyang Go. Collision of adenocarcinoma and schwanoma of the stomach: a case report. The Korean Journal of Pathology 2012;46:373-376.

https://doi.org/10.4132/KoreanJPathol.2012.46.4.373

7. McNeer G, Pack GT. Neoplasm of the stomach. Philadephia: J.B Lippincott, 1975:518-540.

8.Maiorana A FR, Maria Cesinaro A, Adriana Fano R. Synchronous occurrence of epithelial and stromal tumors in the stomach: a report of 6 cases. Arch Pathol Lab Med 2000;124:682-686.

9.Wronski M,Ziarkiewicz-Wroblewska B,Gornicka B. Synchronous occurrence of gastrointestinal stromal tumors and other primary gastrointestinal neoplasms. World J Gastroenterol 2006; 12:5360-2.

https://doi.org/10.3748/wjg.v12.i33.5360

10.Sarlomo-Rikala M MM. Gastric schwannoma: a clinicopathological analysis of 6 cases. Histopathology 1995;27:355-360. https://doi.org/10.1111/j.1365-2559.1995.tb01526.x

11.M. H. Raber CMPZdP, R. Vink, R. Vink and J. M. Klaase. Gastric schwannoma presenting as an incidentaloma on CT-scan and MRI. Gastroenterology Research 2010;3:276-280.

12.Kwon MS LSS, Ahn GH. Schwannomas of the gastrointestinal tract: clinicopathological features of 12 cases including a case of esophageal tumor compared with those of gastrointestinal stromal tumors and leiomyomas of the gastrointestinal tract. Pathol Res Pract 2002;198:605-613.

https://doi.org/10.1078/0344-0338-00309
13.Fujii Y TN, Hosoya Y. et al. Gastric schwannoma: sonographic findings. J Ultrasound Med 2004;23:1527-1530.

https://doi.org/10.7863/jum.2004.23.11.1527

14.Karabulut N MDR, Yang M. Case report: gastric schwannoma: MRI findings. Br J Radiol 2002;75:624-626. https://doi.org/10.1259/bjr.75.895.750624

15.Vinhais SN CRA, Nobre-Leitao C, Cunha TM. Schwannoma of the esophagus: computed tomography and endosonographic finding of a special type of schwannoma. Acta Radiol 2004;45:718-720. https://doi.org/10.1080/02841850410008243

16.Miettinen M VM, Maarit-Sarlomo-Rikala. Gastrointestinal stromal tumors-value of CD34 antigen in their identification and separation from true leiomyomas and schwannomas. Am J Surg Pathol 1995;19:207-216. https://doi.org/10.1097/00000478-199502000-00009

17.Bandoh T IT, Toyoshima H. Submucosal tumors of the stomach: a study of 100 operative cases. Surgery 1993;113:498-506.

18.Basso N RP, De Leo A, Picconi T, Trentino P, Fantini A. et al. Laparoscopic treatment of gastric stromal tumors. Surg Endosc 2000;124:524-526. https://doi.org/10.1007/s004640000021

19.Mekky MA, Yamao K, Sawaki A. et al.Diagnostic utility of EUS-guided FNA in patients with gastric submucosal tumors. Gastrointest Endosc 2010;71:913-9. https://doi.org/10.1016/j.gie.2009.11.044

20.Fujiwara S, Nakajima K, Nishida T. et al. Gastric schwanomas revisited: has precise preoperative diagnosis become feasible? Gastric cancer 2013:16:318-323.

https://doi.org/10.1007/s10120-012-0186-x

\section{SINCHRONINĖ SKRANDŽIO ŠVANOMA IR} ADENOKARCINOMA: ATVEJO PRISTATYMAS A.Šlepavičius, V.Gasilionis, A.Česas

Raktažodžiai: skrandžio švanoma, adenokarcinoma.

Santrauka

Švanomos (neurilemomos) yra gerybiniai, letai augantys navikai, susiformavę iš bet kurio nervo, turinčio Švano ląstelių nerviniame dangale. Skandžio švanomos yra labai reti mezenchiminiai virškinimo trakto navikai, sudarantys tik $0,2 \%$ visų skrandžio navikų. Ypač retais atvejais kartu su skrandžio švanoma nustatoma ir skrandžio adenokarcinoma. Literatūroje aprašyti tik 2 tokie atvejai. Mūsų straipsnyje pristatomas klinikinis atvejis 52 metų moters, kuriai diagnozavome besimptomę skrandžio švanomą bei sinchroninę skrandžio adenokarcinomą.

Adresas susirašinèti: algisle@gmail.com

$2018-12-20$ 